Atıf İçin: Güner A, Güner Ö, Karabay Yavaşoğlu NU, 2021. Giresun Tombul Fındık (Corylus avellana L.) Yağının Serviks, Meme ve Kolon Kanser Hücrelerinde Sitotoksik ve Antianjiyojenik Aktivitesi. Iğdır Üniversitesi Fen Bilimleri Enstitüsü Dergisi, 11(2): 916-926.

To Cite: Güner A, Güner Ö, Karabay Yavaşoğlu NU, 2021. Antiangiogenic and Cytotoxic Activity of Giresun Tombul Hazelnut (Corylus avellana L.) Oil on Cervix, Breast, and Colon Cancer Cells. Journal of the Institute of Science and Technology, 11(2): 916-926.

\title{
Giresun Tombul Fındık (Corylus avellana L.) Yağının Serviks, Meme ve Kolon Kanser Hücrelerinde Sitotoksik ve
} Antianjiyojenik Aktivitesi

\section{Adem GÜNER ${ }^{1 *}$, Özlem GÜNER², Nefise Ülkü KARABAY YAVAŞOĞLU ${ }^{3}$}

ÖZET: Corylus avellana L. çoğunlukla Giresun'da yetişen dünyanın en kaliteli findık türlerinden biridir. Bu çalışma, Giresun Tombul fındık yağının $\left(0.5,5\right.$ ve $\left.50 \mathrm{mg} \mathrm{L}^{-1}\right)$ antikanser ve antianjiyojenik aktivitelerini değerlendirmek amacıyla gerçekleştirilmiştir. Sitotoksisite insan serviks, kolon ve meme kanseri hücreleri üzerinde MTT ve laktat dehidrojenaz salım (LDH) analizleri ile belirlenmiştir. Hücrelerin oksidatif durumu, toplam oksidatif stres (TOS) ve toplam antioksidan kapasite (TAK) yöntemleriyle ortaya konulmuştur. Anti-anjiyojenik aktiviteyi değerlendirmek için civciv koryoallantoik membran (HET-CAM) deneyi kullanılmıştır. Sonuçlarımız, C. avellana yağının özellikle serviks kanseri hücrelerinde daha fazla olmak üzere, serviks ve kolon kanseri hücrelerinin (sırasıyla IC $50=6.5 \pm 0.35 \mathrm{mg} \mathrm{L} \mathrm{L}^{-1} \mathrm{ve}$ IC $50=26.2 \pm 3.15 \mathrm{mg} \mathrm{L}^{-1}$ ) canlılığını önemli ölçüde inhibe ettiğini göstermiştir. Bununla birlikte, findık yağ örneği, LDH salınımında önemli bir inhibisyona yol açarak sitotoksisite ile doğrusal bir korelasyon sergilemiştir. C. avellana yağ örneği konsantrasyona bağlı bir şekilde serviks ve kolon hücrelerinin TAK seviyelerinde önemli bir artışa neden olurken, TOS seviyelerinde istatistiksel olarak önemli azalmaya yol açmıştır. Aynı zamanda, C. avellana yağ örneği yüksek konsantrasyonlarda anti-anjiyojenik etkinlik göstermiştir. Sonuçlar, Giresun findığının umut verici bir antikanser ajan olduğunu ve bununla birlikte terapötik etkinliğini ortaya koymak için daha ileri çalışmalara ihtiyaç olduğunu göstermiştir.

Anahtar Kelimeler: Anjiyojenezis, antikanser, antioksidan, Corylus avellana, oksidatif stres

\section{Antiangiogenic and Cytotoxic Activity of Giresun Tombul Hazelnut (Corylus avellana L.) Oil on Cervix, Breast, and Colon Cancer Cells}

\begin{abstract}
Corylus avellana $\mathrm{L}$. is one of the best quality hazelnut species grown mostly in Giresun province. This present study was realised to evaluate the anticancer and antiangiogenic activities of Giresun Tombul hazelnut oil $\left(0.5,5\right.$ and $\left.50 \mathrm{mg} \mathrm{L}^{-1}\right)$. Cytotoxicity was determined by MTT and lactate dehydrogenase release (LDH) assays on human cervix, colon, and breast cancer cells. Oxidative status was analyzed by total oxidative stress (TOS) and total antioxidant capacity (TAC) assay. Hen's egg test chorioallantoic membrane (HETCAM) assay was used to evaluate the anti-angiogenic activity. Our results showed that $C$. avellana oil had significant anti-proliferative activity against both cervix and colon cancer cells $\left(6.5 \pm 0.35 \mathrm{mg} \mathrm{L}^{-1}\right.$ and $26.26 \pm 3.15 \mathrm{mg} \mathrm{L}^{-1}$, respectively), with more inhibiting the cervix cancers and caused significant inhibition in LDH release as a linear correlation with MTT results. C. avellana oil significantly increased the TAC status on the cervix and colon cells while causing a significant reduction in TOS levels in a dose-dependent manner. $C$. avellana oil had anti-angiogenic effectiveness in higher doses. The results indicated that Giresun hazelnut was a promising anticancer agent and however, further studies are needed to reveal its therapeutic effectiveness.
\end{abstract}

Keywords: Antiangiogenic, anticancer, antioxidant, Corylus avellana, oxidative stress

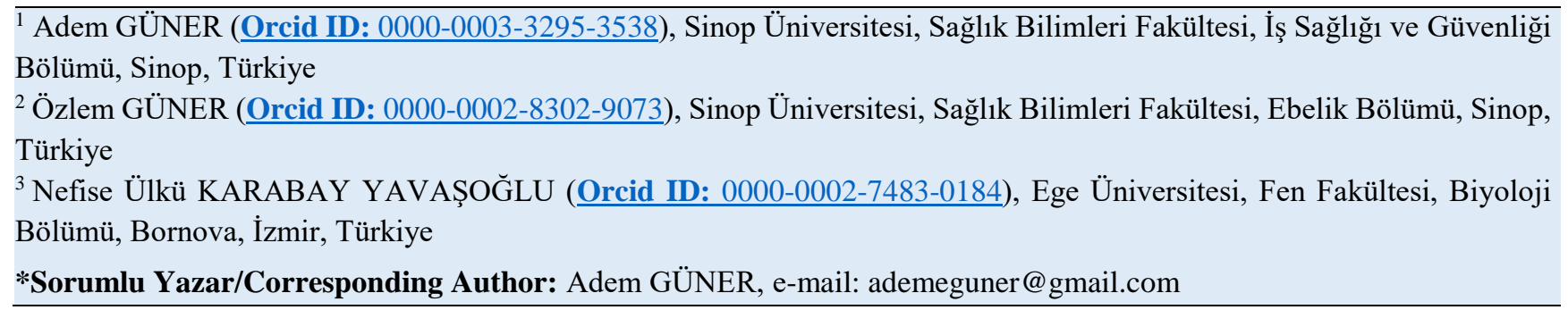




\section{GİRIŞ}

Kanser, hızlı yayılma ve vücudun diğer bölgelerine metastaz yeteneği olan anormal hücre büyümelerini içeren hastalık grubudur. Son yıllarda, dünya çapında teşhis edilen kanser vakalarının ve kanser ölümlerinin sayısında sürekli bir artış olmuştur. Dünya Sağlık Örgütü'nün 2019 yılındaki küresel popülasyona yönelik kanser insidansı verilerine göre, 2018'de 18.1 milyon yeni vaka ve 9.6 milyon ölüm kaydedilmiştir (ACS, 2018). Bu duruma ek olarak, 2025 yılına kadar kanser vakalarının 20 milyonu geçeceği tahmin edilmektedir. Bu rakamlardaki artışlar sıklıkla artan ortalama yaşam süresi, teşhis ve önlemedeki eksiklikler ve özellikle gelişmekte olan ülkelerdeki obezite ve sigara içme alışkanlıkları ya da yaşam tarzındaki değişikliklerden kaynaklanmaktadır. Özellikle, kanser vakalarının \% 40'ının sigara, aşırı kilolu olma, alkol tüketimi, düşük meyve ve sebze alımı, mesleki tehlikeler ve güneşe maruz kalma gibi sağlıksız yaşam tarzı alışkanlıklarıyla bağlantılı olduğu tahmin edilmektedir (Colditz ve ark., 2012). Bununla birlikte, kanser vakalarında diyet uygulamalarının kanser riskini azaltabilme potansiyeline sahip olduğuyla ilişkili kanıtlar giderek artmaktadır (Riboli, 2014). Meyve, sebze, balık ve zeytinyağı açısından zengin bir Akdeniz diyetinin kanser riskini \% 12 azaltabileceği ve doğal içerikli diyet takviyelerinin kanserin önlenmesinde yararlı bir içerik olarak kullanılabileceği sıklıkla rapor edilmiştir (La Vecchia, 2009).

Bitkiler eski çağlardan beri canlılar için önemli bir besin kaynağı olmuştur. Teknolojik gelişmelere bağlı olarak bitkilerin yararlı etkilerinin yapısındaki aktif sekonder metabolitlerden kaynaklandığını ortaya koyan sayısız çalışma yürütülmüştür. Bu bağlamda pek çok bitkinin antioksidan, antikanser, antimikrobiyal, antiülseratif, antibakteriyal, antimutajenik ve antihistaminik gibi etkileri yoğun olarak ortaya konulmuştur (Benetou ve ark., 2008, Güner ve ark., 2019a). Aynı zamanda bitkisel doğal ürünler, medikal endüstrisinde pek çok ilacın hammadesi olarak kullanılmaktadır. Dünya Sağlık Örgütü'ne göre, Amerika Birleşik Devletleri'nde kullanılan modern ilaçların yaklaşık \% 25'i bitkilerden elde edilmiştir. Modern farmakoloji de en az 7.000 tıbbi bileşik, bitkilerden elde edilmektedir (Lui, 2004). Dünya genelinde yoğun bir kullanıma sahip olan fındık ürünleri de, yapısındaki yüksek miktarlardaki mineral, protein, diyet lifi, vitamin ve çoklu doymamış yağ asitlerinden dolayı farmasötik alanda gittikçe artan bir ivmeye sahiptir (Lui, 2003). Yapılan son çalışmalarda özellikle prostat ve kolorektal kanser hücrelerinde findık ve findık yan ürünlerinin antikanser etkinliği ortaya konulmuştur. Aynı zamanda, kemoterapi ilaçlarının etken maddesi olarak kullanılan taksanların fındık ürünlerinde bulunması bu bitkisel ürünleri daha kıymetli hale getirmiştir (Falasca \& Casari, 2012).

Türkiye dünyanın en zengin fındık tedarikçisi konumundadır ve toplam küresel üretimin yaklaşık \% 70'ine katkıda bulunmakta olup, ülkemizi İtalya, ABD ve İspanya izlemektedir (Ciarmiello ve ark., 2004). Türkiye'nin findık ve findık ürünlerinden toplam ihracat geliri yıllık 2 milyar ABD dolarının üstündedir. Karadeniz Bölgesi'nin iklim özellikleri, fındık için en ideal ortamı oluşturur ve farklı türde fındığa ev sahipliği yapmaktadır. Ülkemizdeki kültür fındıkları, 5-6 metre boylanabilir ve bunlar "Corylus avellana" ile "Corylus maxima" türlerinin melezleridir (Köksal ve ark., 2006; Madesis ve ark., 2013). Aynı zamanda, Türk fındığı, kalite olarak Giresun ve Levant olmak üzere ikiye ayrılır. Giresun'un kaliteli fındığı, tadı ve içerdiği yağ oranı ile yeryüzünün en nitelikli fındığı özelliğindedir. Daha az yağlı levant kalite fındık ise Samsun, Ordu, Samsun, Sakarya, Bolu, ve Zonguldak illerinde yetişmektedir (Köksal, 2002). 
Başta Karadeniz bölgesi olmak üzere Türkiye genelinde fındık ve fındık ürünleri sıklıkla gıda maddesi olarak ilgi görürken, tıp ve eczacılık gibi alanlarda beklenen ilgiyi görmemiştir. Bu amaçla mevcut çalışma Giresun ilinden toplanan tombul fındığından (C. avellana) elde edilen yağın antikanser ve antianjiyogenik aktivitelerinin ortaya konulması amacıyla yürütülmüştür.

\section{MATERYAL ve METOT}

Çalışmada kullanılan fındık örnekleri, 2019 yılının Ağustos ayında Tirebolu Karakaya havzasında toplanmıştır. Örneklerin kabuğu uzaklaştırıldıktan sonra, ticari olarak soğuk sıkım fındık yağı satışı gerçekleştiren firma aracılığıyla fındıkların yağı çıkarılmıştır. Elde edilen yă̆ örnekleri deneyin yapılışına kadar $-20^{\circ} \mathrm{C}$ 'de saklanmıştır.

\section{Sitotoksik aktivitenin belirlenmesi (MTT yöntemi)}

F1ndık yă̆ örneğinin sitotoksik etkinliği MCF-7 (İnsan meme adenokarsinom hücre hatt1, ATCCHTB-22), CaCo-2 (İnsan kolon kolektral adenokarsinom hücre hatt1, ATCC-HTB-37), HeLa (İnsan servikal kanser hücre hattı, ATCC-CCL-2) ve normal HEK-293 (insan embriyonik böbrek hücre hatt1, ATCC-CRL-1573) hücre hatlarında belirlenmiştir.

Tüm hücre hatları, 1 x $10^{5}$ hücre/ml başlangıç hücre konsantrasyonun da 96 kuyucuklu plakalara yetiştirilmiştir. Hücreler, 24 saat sonra farklı konsantrasyonlarda $\left(0.5,5\right.$ ve $\left.50 \mathrm{mg} \mathrm{L}^{-1}\right)$ örneklerle işlem uygulanmış ve pozitif kontrol için $\left(0.2,2\right.$ ve $\left.20 \mathrm{mg} \mathrm{L}^{-1}\right)$ doksorubisin kullanılmıştır. Çözünmüş malzemenin optik yoğunlukları (OD), 48 saat sonra UV görünür spektrofotometre ile $570 \mathrm{~nm}$ 'de belirlenmiştir. Canlı hücrelerin yüzdesi, spektrofotometrik ölçümle belirlenmiştir. Her bir hücre hattı için uygulanan konsantrasyonda, kontrol ile karşılaştırılarak, hücre canlılığı ve maddelerin IC50 değerleri hesaplanmıştır. Hesaplamada GraphPad Prism 5 programı kullanılmıştır.

$\%$ Canlılık $=100 \mathrm{x}$ Uygulanan konsantrasyondaki ortalama absorbans / Kontrol hücre absorbans1

\section{Laktat dehidrogenaz (LDH) salınımı analizi}

Fındık yă̆ örneğinin sitotoksik etki göstererek ortaya çıkardıkları LDH salınım seviyelerini belirlemek amacıyla ticari LDH sitotoksisite kiti (Cayman, ABD) kullanılmıştır. Test prosedürü, laktatın piruvat oksidasyonu aracılığı ile $\mathrm{LDH}, \mathrm{NAD}^{+1} 1 \mathrm{n}$ NAD ve $\mathrm{H}^{+1}$ a indirgenmesini katalizlemeye dayanmaktadır. LDH testinin denemelerde kullanılmasının temel sebebi hücrelerin nekroz sonucu hasar görüp görmediklerinin tespit edilmesidir. Ayrıca gerçekleştirilen sitotoksisite analizlerini desteklemek amacıyla LDH testi tercih edilmiştir. LDH testleri için pozitif kontrol olarak mitomisin-C kullanılmıştır.

\section{Toplam antioksidan kapasite (TAK) ve toplam oksidative stres (TOS) analizi}

Fındık örneğinin hücreler üzerinde TAK seviyelerini belirlemek amacıyla ticari TAK kiti (Rel Assay Diagnostics, Türkiye) kullanılmıştır (Güner \& İlhan, 2020). Kitin uygulamasında amaç, kullanılan örneklerin bir serbest radikal olan 2,2'-azino-bis(3- etilbenzotiyazolin-6-sülfonik asit) (ABTS) bileşiğinin oluşumunu inhibe etmek suretiyle sahip oldukları antioksidan düzeylerini belirlemektir. Kit uygulaması, vitamin E analoğu olan ve Troloks eşdeğeri olarak adlandırılan kararlı bir antioksidan ile kalibre edilmektedir. TAK testleri için pozitif kontrol olarak askorbik asit kullanılmıştır.

Fındık yă̆ örneğinin hücreler üzerinde TOS düzeylerini belirlemek amacıyla ticari TOS kiti (Rel Assay Diagnostics, Türkiye) kullanılmıştır. Kit uygulamasında, örnekte mevcut olan oksidan maddeler, demir iyonu içeren kompleksleri demir iyonuna oksitlemektedir. Demir iyonları asidik ortamda kromojen 
ile renkli bir yapı oluşturmaktadır. Spektrofotometrik olarak ölçülen renk yoğunluğu, örnekte bulunan oksidan moleküllerinin toplam miktarı ile ilişkilidir. Kit uygulaması hidrojen peroksit $\left(\mathrm{H}_{2} \mathrm{O}_{2}\right)$ ile kalibre edilmektedir. TOS testleri için pozitif kontrol olarak $\mathrm{H}_{2} \mathrm{O}_{2}$ kullanılmıştır.

\section{Koryoallantoik membran yöntemi (HET-CAM) ile antianjiyogenik aktivitenin belirlenmesi}

Fındık yağ örneğinin antianjiojenik etkilerini ortaya koymak amacıyla döllenmiş tavuk yumurtaları üzerinde, koryoallantoik membran modeli uygulaması gerçekleştirilmiştir. 50-60 gr ağırlığında, Leghron tavuk yumurtalarında analiz gerçekleştirilmiştir. Döllenmiş yumurtalar, $37 \pm 1^{\circ} \mathrm{C}^{\prime} \mathrm{de}$, \% $58 \pm 2$ nem oranında 5 gün kuluçka makinasında inkübasyona bırakılmışlardır. 5. günde yumurtalar çıkartılmış, hava boşluğu (künt) olan yerden işaretleme yapılmış ve o bölgeden 25 mm'lik disk şeklinde yumurta kabuğu kaldırılmıştır. Membran \% 9'luk $\mathrm{NaCl}$ ile nemlendirildikten sonra yumurtalar tekrar inkübatöre yerleştirilmiş ve 30 dakika inkübasyona bırakılmıştır. Koryoallantoik membran, yaklaşık $2 \mathrm{~cm}$ çapa ulaştığında $0.3 \mathrm{~mL}$ fındık örnekleri direkt olarak uygulanmıştır. Pozitif ve negatif kontrol maddeleri de aynı miktarda uygulanmıştır. Kabuktaki bu açıklık laboratuvar filmi ile kapatılmıştır. Her bir test bileşiğinin her bir konsantrasyonu için 5 yumurtaya uygulama yapılmış ve tüm testler iki kez tekrarlanmıştır. Uygulama sonucunda örnekler hemoraji, vasküler lizis ve koagülasyon bakımından değerlendirildikten sonra elde edilen skorlar aşağıdaki formül kullanılarak hesaplanmıştır. 24 saatlik inkübasyon süresinin sonunda irritasyon etkisi, stereomikroskop altında skorlama tablosunu takiben incelendi. Skorlama şu şekildedir;

Irritasyon skoru $=[(301-\mathrm{h}) \times 5] / 300+[(301-1) \times 7] / 300+[(301-c) \times 9] / 300$

Burada, h (hemoraji); vasküler kanamanın meydana geldiği zamandır, 1 (lizis); ilk vasküler parçalanmanın meydana geldiği zamandır ve c (koagülasyon); vasküler pıhtılaşmanın ilk meydana geldiği zamandır. IS'ye göre tahriş sınıflandırması: < 0.9; tahriş edici olmayan, 1-4.9; hafif tahriş, 5-8.9; orta derecede tahriş ve 9-21, şiddetli tahriş edici etki.

\section{İstatistiksel analiz}

İstatistiksel analiz SPSS 20 (SPSS, Chicago, IL, ABD) kullanılarak yapıldı. Deneysel veriler tek yönlü varyans analizi (ANOVA) ile analiz edilmiş, daha sonra uygulama ve kontrol grupları arasında herhangi bir fark olup olmadığını incelemek için Duncan testi yapılmıştır. Veriler arasındaki korelasyonları belirlemek için Pearson'ın $r$ katsayısı kullanıldı. Sonuçlar ortalama \pm SD değerleri olarak verildi ve p <0.05 anlamlı kabul edilmiştir. Tüm deneyler üç kez tekrarland1.

\section{BULGULAR ve TARTIŞMA}

C. avellana Betulaceae familyasına ait olup ve dünyadaki en popüler ağaç formlarından biridir. Her fındık çeşidinin kendine has besinsel bileşimi, özgü tadı ve aroması bulunmaktadır. Giresun ilinde yetişen Tombul (yuvarlak) fındık, Türkiye'de yetiştirilen 17 ticari fındık ürün arasında birinci sınıf kaliteye sahip olup aynı zamanda dünyanın en kaliteli fındık türlerinden biri olduğu bilinmektedir (Alasalvar ve ark., 2003). Daha önceki çalışmalarda lipit, karbonhidrat, mineral ve vitamin gibi aktif bileşenlere sahip olduğu ortaya konulan Giresun Tombul fındığının, kanser hücrelerine karşı etkinliğiyle ilgili yeterli çalışma bulunmamaktadır. Bu çalışmada, C. avellana yağ örneklerinin kolon, meme ve serviks kanser hücrelerine karşı sitotoksik etkinlik gösterdiği ortaya konulmuştur. 
Kanser, yaşam ve beslenme tarzının değişmesi ile birlikte artış gösteren korkunç bir hastalık olup, başlama, çoğalma ve ilerleme gibi en az üç aşamada tanımlanan çok kademeli bir süreçtir (Green \& Red, 1998). Bu safhaların ortaya çıkmasında en etkili faktörlerin, çeşitli ajanlar tarafından hücrelerde uyarılmış oksidatif stres kaynaklı olduğu bilinmektedir (Güner ve ark., 2019b). İlk aşamada, reaktif oksijen türleri (ROS), DNA'da gen mutasyonları ve yapısal değişiklikler oluşturarak DNA hasarı meydana getirebilir. Bununla birlikte, ROS, anormal gen ekspresyonuna, hücre-hücre iletişiminin bloke edilmesine ve ikinci mesajcı sistemlerin modifikasyonuna yol açarak hücrelerin çoğalmasında bir artışa veya başlatılan hücre popülasyonunun apoptozisinde bir azalmaya neden olmaktadır (Reuter ve ark., 2010; Güner ve ark., 2020). Bu kritik etkilerinden dolayı kanserin herhangi bir sürecine müdahil olarak, oksidatif stresi azaltmaya yönelik doğal bileşiklerin kullanılması hayati önem taşımaktadır. Bu çalışmamızda antioksidan etkileri bilinen tombul fındık yağının kanser hücrelerinde sitotoksik etkileri MTT test yöntemiyle belirlenmiştir. Çalışmamızda $C$. avellana yă̆ örneğinin farklı konsantrasyonları $\left(0.5,5\right.$ ve $\left.50 \mathrm{mg} \mathrm{L}^{-1}\right)$ kullanılmıştır. Her üç konsantrasyonda da kanser hücre hatları (MCF-7, CaCo-2 ve HeLa) ve normal hücre hattı HEK-293 üzerindeki sitotoksik etkisi hücrelerin \% 50'sinin çoğalmasını inhibe eden konsantrasyon olarak tanımlanan IC50 değeri hesaplanarak belirlenmiştir. Madde maruziyetine bağlı olarak kanser hücre hatlarında gözlemlenen hücre canlılık değerleri farklılıklar göstermiştir (Şekil 1). Test örneklerinin en etkili olduğu hücre hattı HeLa olarak tespit edilirken (6.5 \pm $0.35 \mathrm{mg} \mathrm{L}^{-1}$ ), MCF-7 hücre hatlarında hesaplanabilir bir IC50 değeri hesaplanmamıştır. CaCo-2 hücre hattı incelendiğinde ise, $26.26 \pm 3.15 \mathrm{mg} \mathrm{L}^{-1}$ IC50 değeriyle inhibe edici etkiler gözlenmiştir. Benzer olarak, Esposito ve ark., (2017) A375, SK-Mel-28 ve HeLa kanser hücrelerinde C. avellana'nın etkinliğini inceledikleri çalışmada, fındık ekstresinin HeLa hücrelerinin canlılığını önemli ölçüde inhibe ettiğini göstermişlerdir. Hücresel toksisitenin değerlendirilmesinde en önemli göstergelerden biri hasarlı/ölü hücrelerden hücresel ortama laktat dehidrojenaz (LDH) enziminin salınım seviyelerinin ölçülmesidir. Hücreler, toksik etkilere maruz kaldığında plazma membran bütünlükleri bozulur ve sitoplazmik bir enzim olan LDH hücrelerden sıarak ortama geçer (Koh ve ark., 2017; Güner, 2020). Böylece maruziyet sonrası LDH enzim aktivitesi ölçülerek hücre hasarı değerlendirilebilir. Mevcut çalışmamızda fındık uygulamalarından sonra HeLa ve CaCo-2 kanser hücrelerindeki sitotoksik etkinlik LDH salınımı testi ile aktivitesi ilk defa ortaya konulmuş ve sitotoksisite bulgularını destekleyici sonuçlar elde edilmiştir. (Şekil 2). Fındık yağ örneğiyle muamele edilen hücre hatları kontrol grubu ile kıyaslandığında, konsantrasyon artışına bağlı olarak HeLa ve CaCo-2 hücrelerinde LDH salınımı sırasıyla \% 52 ve \% 40 oranında inhibe olmuştur ( $\mathrm{p}<0.05)$. MCF-7 hücrelerinde ise uygulamalar sonrası LDH salınımında istatistiki olarak anlamlı değişim bir olmamıştır. Bununla birlikte, LDH ve sitotoksisite denemeleri arasında korelatif bir ilişki tespit edilmiştir $\left(\mathrm{R}^{2}=0.999\right)$. Corylus türlerinden izole edilen farklı peptid türlerinin insan umbilikal ven endotel hücrelerinde oksidatif stres hasarlarına karşı artan antioksidan düzeyleri ve LDH salınımının inhibisyonu aracılığıyla sitoprotektif etkiler sergilediği ortaya konulmuştur (Fang ve ark., 2018). 


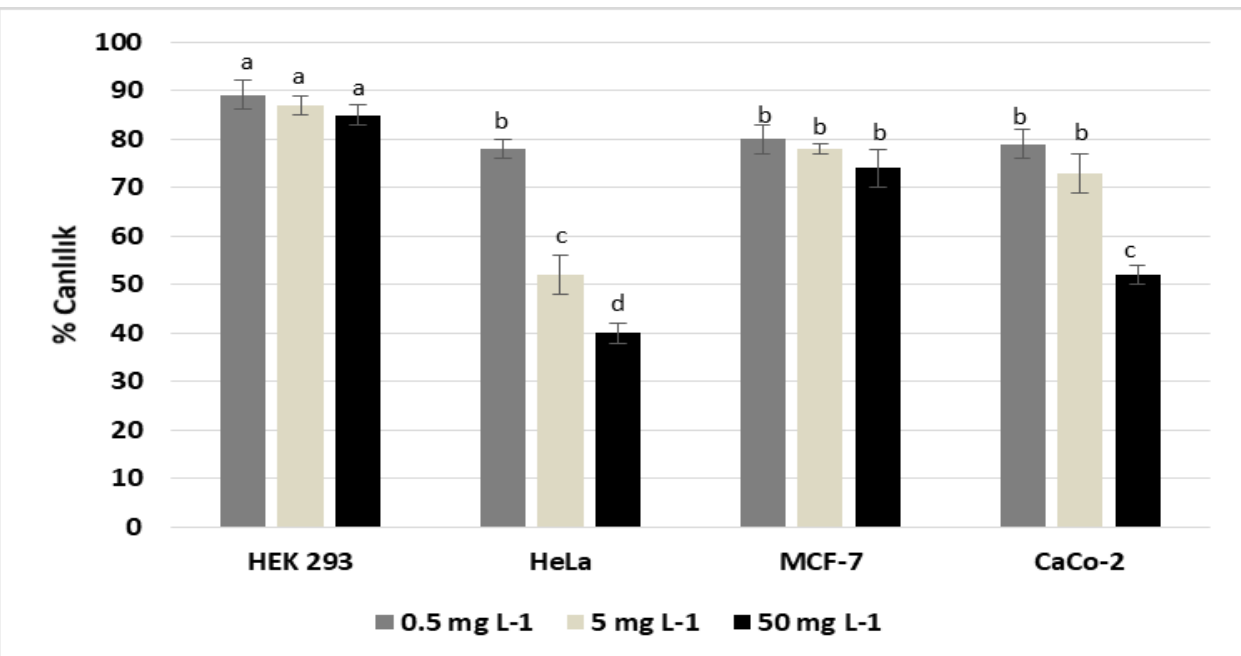

Şekil 1. C. avellana'nın farklı hücre hatları üzerindeki sitotoksik etkileri. Değerler ortalama $\pm \operatorname{SD}(n=5)$ olarak ifade edilmiş ve aynı sütunda bulunan ve farklı üstyazı harfleri ile gösterilen değerler ( $a, b, c, d) p<0.05$ düzeyinde istatistiksel olarak birbirinden anlamlı farklılıkları gösterir

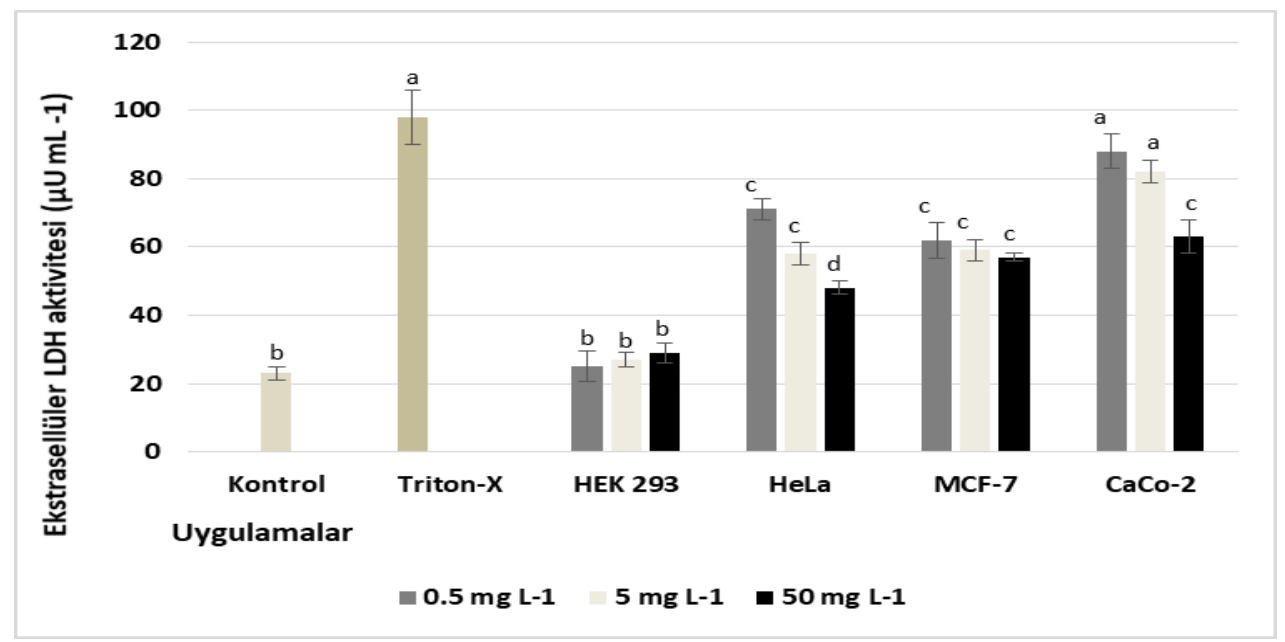

Şekil 2. C. avellana'nın farklı konsantrasyonlarına maruz bırakılan hücre hatlarında laktat dehidrojenaz (LDH) seviyeleri. Değerler ortalama $\pm \operatorname{SD}(n=5)$ olarak ifade edilmiş ve aynı sütunda bulunan ve farklı üstyazı harfleri ile gösterilen ( $a, b, c$, d) değerler $\mathrm{p}<0.05$ düzeyinde istatistiksel olarak birbirinden anlamlı farklılıkları gösterir (a: kontrol grubuna kıyasla anlamlı; b, $\mathrm{c}$ ve d: Triton-X grubuna kiyasla anlamlı)

Kanser olgularının ortaya çıkmasında en etkili faktörlerden biri çeşitli eksojen veya endojen kaynaklar tarafından hücrelerde uyarılan ROS seviyelerindeki artışlardır. Bu artışların neden olduğu oksidatif stres, DNA hasarlarının yanı sıra antiapoptotik genlerin ekspresyonunda artışlara, normal hücresel bölünmelerde kontrol edilemeyen bir anormal hücre çoğalmasına ve sonuçta hücre siklusunda düzensizliklere neden olmaktadır (Visconti \& Grieco, 2006; Liou \& Storz, 2010; Valko ve ark., 2011). Bu kritik etkilerinden dolayı, doğal ajanlarla kanserin oluşumu veya ilerleyişini önleyici stratejiler hayati önem taşımaktadır. Son zamanlarda, Fischer \& Glei (2013), findık ve fistık yağlarının, sızma zeytinyağına yakın ve ceviz, badem ve yer fistığı yağlarından daha yüksek bir antioksidan kapasite sergilediğini bulmuşlardır. Başka bir çalışmada da, fındık ekstresinin yüksek antioksidan kapasite gösterdiği bildirilmiştir (Schmitzer ve ark., 2011). Fındık yă̆ örneği uygulamalarından sonra hücre hatlarındaki oksidan/antioksidan durumdaki değişimler Şekil 3 ve 4'de gösterilmiştir. Bu bağlamda, 
findık yağ örneği uygulamalarından sonra, konsantrasyon artışına bağlı olarak uygulamalardan sonra HeLa ve CaCo-2 hücrelerinin antioksidan durumunda sirasıyla \% 60 ve \% 49 oranında istatistiksel olarak anlamlı bir atış $(\mathrm{p}<0.05)$ görülürken, oksidatif seviyelerde sırasıyla \% 31 ve \% 25 oranında istatistiksel olarak anlamlı $(\mathrm{p}<0.05)$ azalmalar görülmüştür. MCF-7 hücrelerinde ise findık yă̆ örneği uygulamaları antioksidan ve oksidan seviyeler de herhangi bir değişime yol açmamıştır. Yağ örneklerinin kanser hücrelerine karşı farklı inhibisyon etkileri, kanser hücrelerinin direnç yetenekleri ve yăg ekstraksiyonun yapısındaki farklı metabolitlerinin farklı hücresel yolaklarla etkileşime girmesiyle açıklanabilir. Bununla birlikte, fındık yağının var olan sitotoksik etkileri, hem serbest oksijen radikallerin üretimini baskılayarak hem de antioksidan sürece katkıda bulanarak kanser hücrelerinin canlılığını baskılamasıyla ortaya çıktığı düşünülmüştür.

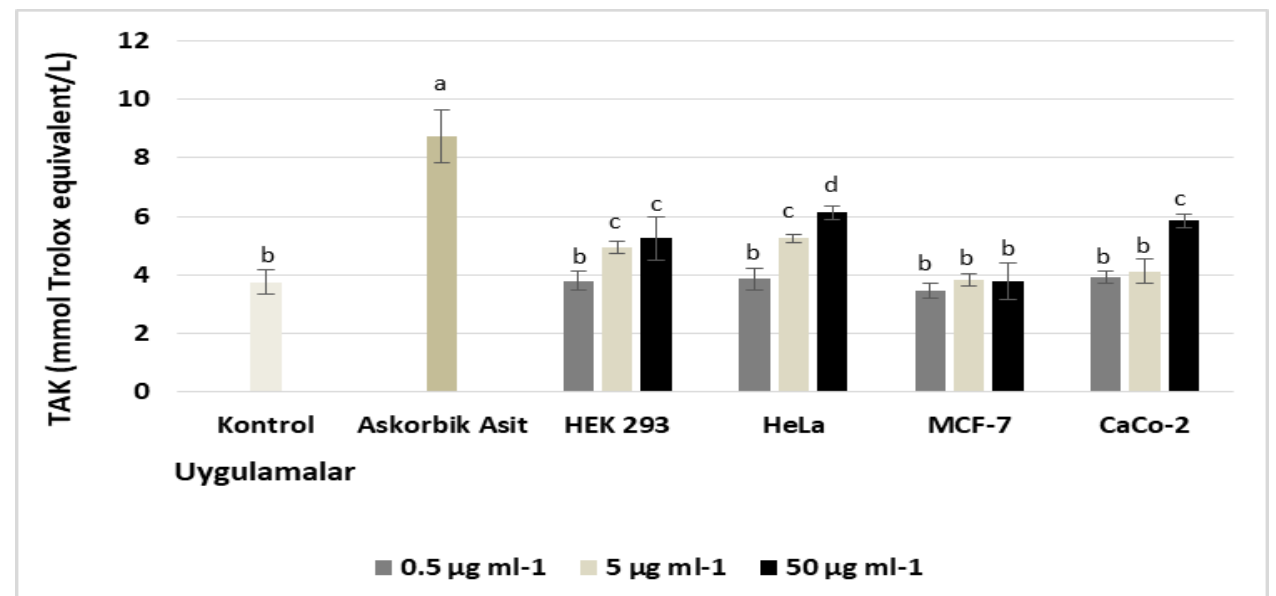

Şekil 3. C. avellana'nın farklı konsantrasyonlarına maruz bırakılan hücre hatlarında total antioksidan kapasiteleri seviyeleri. Değerler ortalama \pm SD $(n=5)$ olarak ifade edilmiş ve aynı sütunda bulunan ve farklı üstyazı harfleri ile gösterilen (a, b, c, ve d) değerler $\mathrm{p}<0.05$ düzeyinde istatistiksel olarak birbirinden anlamlı farklılıkları gösterir (a: kontrol grubuna kıyasla anlamlı, b, c ve d: Askorbik asite kıyasla anlamlı)

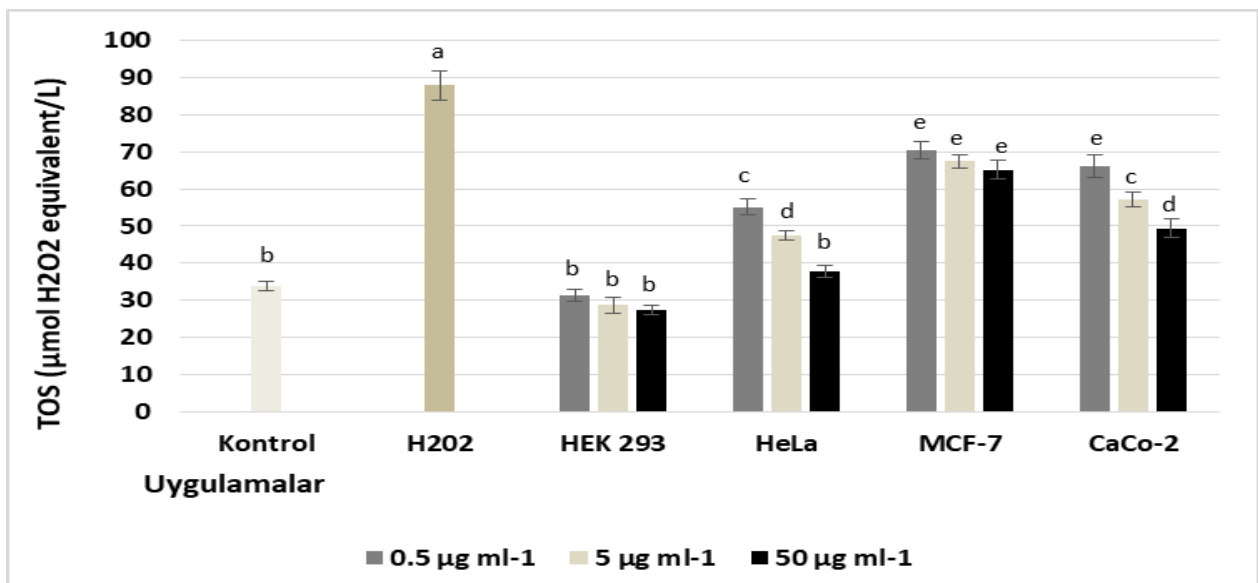

Şekil 4. C. avellana'nın farklı konsantrasyonlarına maruz bırakılan hücre hatlarında total oksidan kapasite seviyeleri. Değerler ortalama \pm SD $(n=5)$ olarak ifade edilmiş ve aynı sütunda bulunan ve farklı üstyazı harfleri ile gösterilen $(a, b, c, d$, and e) değerler $\mathrm{p}<0.05$ düzeyinde istatistiksel olarak birbirinden anlamlı farklılıkları gösterir. (a: kontrol uygulama grubuna kıyasla anlaml, b, c ve d: $\mathrm{H}_{2} \mathrm{O}_{2}$ grubuna kiyasla anlaml1, ) 


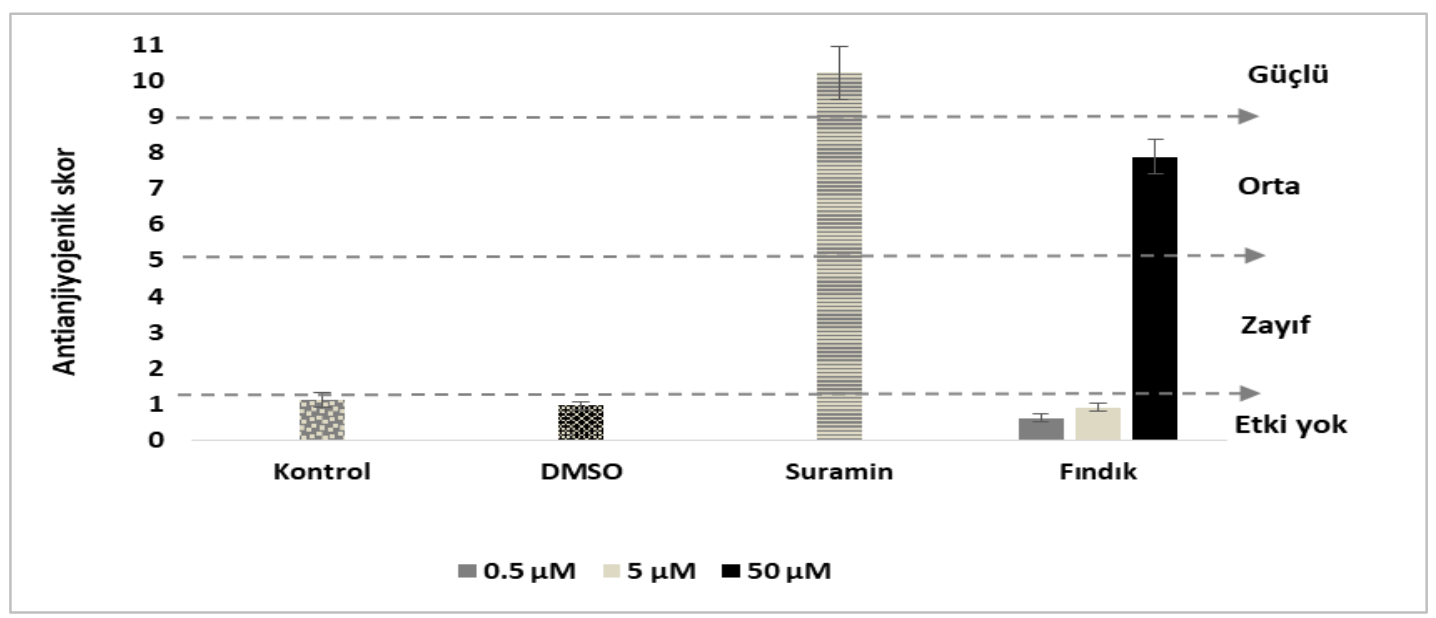

Şekil 5. C. avellana'nın farklı konsantrasyonlarının CAM yüzeyindeki 5 dakikalık maruziyeti takiben ortalama tahriş skoru

Anjiyojenez, yara iyileşmesi, doku büyümesi ve rejenerasyon gibi normal fizyolojilerde kan damarlarının oluşumunun gerçekleştiği karışık süreçlerdir. Anjiyojenez süreci yeni damar oluşumundan çok var olan damarlardan yan dal ve filiz oluşumlarıyla meydana gelen damarlanmalar olarak bilinmektedir (Kim \& Byzova, 2014). Anjiyojenez de normal fizyolojik koşullar altında, proanjiyogenik ve antianjiyogenik faktörler arasında bir denge vardır, ancak bu denge, fizyolojik süreçleri teşvik etmek için ya da patolojik bir durumun bir parçası olarak her iki tip arabulucuya doğru kayabilir (Güner \& Karabay Yavaşoğlu, 2018). Bu durumda anjiyojenez sağlıklı hücreler için vazgeçilmez bir kaynak olan damar oluşumunu ifade etse de, kanser gibi metabolizması hızlı ilerleyen durumlarda ise canlılık için hayati risk taşımaktadır (Folkman, 1995). Anjiyojenez kanser hücrelerinin başta hipoksi olmak üzere belirli uyaranlara maruz bırakılmasıyla aktive edilir ve tümör fazla büyüdüğünde vasküler endotelyal büyüme faktörlerini etkileyerek yeni kaynaklara ulaşım sağlar (Eming ve ark., 2007). Bu yeni kan damarlarının gelişimi sadece tümör dokusunun besin maddeleri ile beslenmesini sağlamakla kalmaz, aynı zamanda kanser hücrelerinin metastazı için bir araç olabilmektedir (Nishida et al., 2006). Son yıllarda, kanserin antianjiyojenez sürecine müdahele sürecinde direkt olarak tümörü hedef almaktan ziyade, beslenmesini sağlayan damarlanma mekanizmasını inhibe eden çalışmalar tasarlanmıştır. Bu süreç, endotelyal büyüme faktörleri inhibitörleri, endotel hücre sinyal transdüksiyon inhibitörleri, endotel hücre proliferasyonunun önleyicileri, matris metaloproteinaz inhibitörleri ve endotel kemik iliği öncü hücrelerinin inhibitörleri gibi hedef anjiyojenez inhibitörlerinin kullanılmasıyla gerçekleştirilir (Denekamp, 1993; Muslim ve ark., 2012). Yürütülen birçok çalışma da, doğal kaynaklı anti-anjiyojenik ilaç uygulamalarının, yan etkileri azaltmada geleneksel kanser tedavisine kıyasla daha etkili olduğu, tümörü besleyen yeni kan damarlarının oluşumunu inhibe ettiği ve bu süreçte ilaç direnci olasılığının düşük olduğu bildirilmektedir (Ciardiello ve ark., 2000). Findık yağ örneklerinin uygulamasına yanıt olarak ortaya çıkan lizis, kogülasyon ve hemoroji gibi antianjiogenik etkinliği kanıtlamak amacıyla HETCAM yöntemi ile gerçekleştirilmiş ve değerlendirme sonucunda elde edilen skorlar Şekil 5'de gösterilmiştir. Pozitif kontrol olarak antianjiogenik etkinliği kanıtlanmış süramin, negatif kontrol olarak ise $\mathrm{NaCl}$ kullanılmıştır. Çalışmada çözgen olarak kullanılan DMSO'nun herhangi bir etkisi tespit edilmemiş̧ir. Pozitif kontrol (süramin), CAM ile etkileşime girerek 5 dakikalık bir süre için kanama, liziz ve pıhtılaşma ile sonlanan $10.97 \pm 2.04$ skor ile antianjiyogenik aktivite sergilemiştir. $50 \mathrm{mg} \mathrm{L}^{-1}$ da 
fındık örneği, 5 dakikalık süre zarfında vasküler etkileri takiben $7.92 \pm 0.9$ 'lik bir skorlama ile orta bir etki göstermiştir. Bununla birlikte, daha düşük konsantrasyon uygulamalarında herhangi değişim olmamıştır. Benzer olarak, Falasca ve ark., (2014) ellagik asit, anakardik asit, genistein, resveratrol ve inositol fosfatlar gibi biyoaktif bileşikler içeren findığın, kanser sürecinde hücre döngüsünü etkileyerek, apoptozisin aktivasyonunun yanısıra hücre proliferasyonu, migrasyonu ve anjiyojenezin inhibisyonu üzerinden kanser riskini azaltabileceğini ortaya koymuştur.

\section{SONUÇ}

Sonuç olarak, fındık hem içerdiği biyoaktif bileşikler hem de lezzeti bakımından günümüze kadar önemli bir besin kaynağı haline gelmiştir. Mevcut çalışmada, Giresun findığından elde edilen yağ örneklerinin serviks ve kolon kanser hücreleri üzerinde hem antioksidan kapasiteyi arttırıp hemde ROS üretimini baskılayarak önemli bir sitotoksik etki sergilediği görülmüştür. Bu bağlamda, yüksek konsantrasyonlardaki antianjiyogenik aktivelerde göz önüne alındığında, Giresun tombul findığının kalite olarak birçok alanda tercih edilmesinin yanı sıra ileri laboratuvar teknikleriyle de desteklenerek bir antikanser ajanı olarak geliştirilme potansiyeline sahip olduğu ortaya konulmuştur.

\section{TEŞEKKÜR}

$\mathrm{Bu}$ çalışma, Giresun Üniversitesi Bilimsel Araştırma Projeleri Koordinasyon Birimi tarafından "FEN-BAP-A-150219-28” kodlu proje ile desteklenmiştir.

\section{Çıkar Çatışması}

Yazarlar herhangi bir çıkar çatışması olmadığını bildirmişlerdir.

\section{Yazar Katkısı}

Güner A., ve Karabay Yavaşoğlu N.U. çalışmayı tasarladı. Güner A., hücre kültür çalışmalarını ve diğer enzim çalışmalarını gerçekleştirdi ve makaleyi düzenledi. Güner A., ve Güner Ö., antianjiyojenik denemeleri gerçekleştirdi ve çalışmanın sonuçlarını ve istatistiksel analizlerini gerçekleştirdi.

\section{KAYNAKLAR}

ACS, 2018. Cancer Facts and Figures. American Cancer Society, New York, NY, USA.

Alasalvar C, Shahidi F, Liyana-Pathirana C, Ohshima T, 2003. Turkish Tombul hazelnut (Corylus avellana L.). 1. Composition characteristics. Journal of Agricultural and Food Chemistry, 51(13): 3790-3796.

Benetou V, Trichopoulou A, Orfanos P, Naska A, Lagiou P, Boffetta P, Trichopoulos D, 2008. Greek EPIC cohort. Conformity to traditional Mediterranean diet and cancer incidence: the Greek EPIC cohort. British Journal of Cancer, 99(1): 191-195.

Ciardiello F, Caputo R, Bianco R, Damiano V, Pomatico G, De Placido S, Bianco AR, Tortora G, 2000. Antitumor effect and potentiation of cytotoxic drugs activity in human cancer cells by ZD-1839 (Iressa), an epidermal growth factor receptor-selective tyrosine kinase inhibitor. Clinical Cancer Research, 6(5): 2053-63.

Ciarmiello LF, Mazzeo MF, Minasi P, Peluso A, de Luca A, Piccirillo P, Siciliano RA, Carbone V, 2014. Analysis of Different European Hazelnut (Corylus avellana L.) Cultivars: Authentication, Phenotypic Features, and Phenolic Profiles. Journal of Agricultural and Food Chemistry, 62(26): 6236-6246.

Colditz GA, Wolin KY, Gehlert S, 2012. Applying what we know to accelerate cancer prevention. Science Translational Medicine, 4(127): 127-1244. 
Denekamp J, 1993. Review article: angiogenesis, neovascular proliferation and vascular pathophysiology as targets for cancer therapy. British Journal of Radiology, 66(783): 181-96.

Eming SA, Brachvogel B, Odorisio T. Koch M, 2007. Regulation of angiogenesis: Wound healing as a model. Progress in Histochemistry and Cytochemistry, 42(3): 115-170.

Esposito T, Sansone F, Franceschelli S, Del Gaudio P, Picerno P, Aquino RP, Mencherini T, 2017. Hazelnut (Corylus avellana L.) Shells Extract: Phenolic Composition, Antioxidant Effect and Cytotoxic Activity on Human Cancer Cell Lines. International Journal of Molecular Sciences, 18(2): 392.

Falasca M. Casari I, 2012. Cancer chemoprevention by nuts: evidence and promises. Frontiers in bioscience (Scholar edition), 4: 109-120.

Falasca, M., Casari, I. \& Maffucci, T, (2014). Cancer chemoprevention with nuts. Journal of the National Cancer Institute, 106(9): dju238.

Fang L, Ren D, Wang Z, Liu C, Wang J, Min W, 2019. Protective role of hazelnut peptides on oxidative stress injury in human umbilical vein endothelial cells. Journal of Food Biochemistry, 43(3): e12722.

Fischer S, Glei M, 2013. Health-Potential of Nuts. Ernaehrungs Umschau international, 60, 206-215.

Folkman J. 1995. Angiogenesis in cancer, vascular, rheumatoid and other disease, Nature medicine, 1(1): 27-31.

Green DR, Reed JC, 1998. Mitochondria and apoptosis. Science, 281: 1309-1312.

Güner A, Karabay Yavaşoğlu NÜ, 2018. Evaluation of antioxidant, antimicrobial and antimutagenic activity with irritation effects of Ceramium rubrum (Red Algae) extract. International Journal of Secondary Metabolite, 5(4): 279-287.

Güner A, Polatlı E, Akkan T, Bektaş H, Albay C, 2019a. Anticancer and antiangiogenesis activities of novel synthesized 2-substituted benzimidazoles molecules. Turkish Journal of Chemistry, 43(5): 1270-1289.

Güner A, Nalbantsoy A, Sukatar A., Karabay Yavaşoğlu NU, (2019b). Apoptosis-inducing activities of Halopteris scoparia L. Sauvageau (Brown algae) on cancer cells and its biosafety and antioxidant properties. Cytotechnology, 71(3): 687-704.

Güner A, Kızılşahin S, Nalbantsoy A, Karabay Yavaşoğlu NU, 2020. Apoptosis-inducing activity of safflower (Carthamus tinctorius L.) seed oil in lung, colorectal and cervix cancer cells. Biologia 75: 1465-1471.

Güner A, 2020. Toxic and irritant effects induced by zearalenone: prevention by taurine. Toxin Reviews, 1-10. Doi: 10.1080/15569543.2020.1777432

Güner A, İlhan S, 2020. Cytotoxic, genotoxic, oxidative, and irritant effects of zinc pyrithione in vitro. Toxicological \& Environmental Chemistry, 102(10): 607-623

Köksal AI, 2002. Türk Fındık Çeşitleri. A.Ü. Ziraat Fakültesi Bahçe Bitkileri Bölümü, Ankara. ISBN 975-92886$0-5$.

Köksal AI, Artik N, Simsek A, Gunes N, 2006. Nutrient Composition of Hazelnut (Corylus avellana L.) Varieties Cultivated in Turkey. Food Chemistry, 99(3): 509-515.

Kim, Y.W. \& Byzova, T.V. (2014). Oxidative stress in angiogenesis and vascular disease, Blood, 123: 625-631.

Koh YW, Lee SJ, Park SY, 2017. Prognostic significance of lactate dehydrogenase B according to histologic type of non-small-cell lung cancer and its association with serum lactate dehydrogenase. Pathology-Research and Practice, 213: 1134-1138.

La Vecchia C, 2009. Association between Mediterranean dietary patterns and cancer risk. Nutrition Reviews, 67(1): 126-129.

Lui RHJ, 2003. Health benefi ts of fruits and vegetables are from additive and synergestic combination of phytochemicals. The American Journal of Clinical Nutrition,78: 517-520.

Lui RHJ, 2004. Potential synergy of phytochemicals in cancer prevention: mechanism of action. Journal of Nutrition, 134: 3479-3485.

Liou GY, Storz P, 2010. Reactive oxygen species in cancer. Free Radical Research, 44: 479-496. 
Madesis P, Ganopoulos I, Bosmali I, Tsaftaris A, Barcode H, 2013. Resolution Melting analysis for forensic uses in nuts: A case study on allergenic hazelnuts (Corylus avellana). Food Research International, 50, 351-360.

Muslim N, Nassar Z, Aisha A, Shafaei A, Idris N, Majid A, Ismail Z, 2012. Antiangiogenesis and antioxidant activity of ethanol extracts of Pithecellobium jiringa. BMC Complementary Medicine and Therapies, 12: 210.

Nishida N, Yano H, Nishida T, Kamura T, Kojiro M, 2006. Angiogenesis in cancer. Vascular Health and Risk Management, 2: 213-219.

Reuter S, Gupta SC, Chaturvedi MM, Aggarwal BB, 2010. Oxidative stress, inflammation, and cancer: how are they linked? Free radical biology \& medicine, 49(11): 1603-1616.

Riboli E, 2014. The role of metabolic carcinogenesis in cancer causation and prevention: evidence from the European Prospective Investigation into Cancer and Nutrition. Cancer Treatment and Research, 159: 3-20.

Schmitzer V, Slatnar A, Veberic R, Stampar F, Solar A, 2011. Roasting affects phenolic composition and antioxidative activity of hazelnuts (Corylus avellana L.). Journal of Food Science, 76: 14-19.

Valko M, Rhodes C, Moncol J, Izakovic MM, Mazur M, 2006. Free radicals, metals and antioxidants in oxidative stress-induced cancer. Chemico-biological interactions, 160(1): 1-40.

Visconti R, Grieco D, 2009. New insights on oxidative stress in cancer. Current opinion in drug discovery \& development, 12(2): 240-245. 